\begin{tabular}{|c|c|c|c|c|c|c|c|c|c|c|c|}
\hline \multicolumn{4}{|c|}{$\begin{array}{l}\text { 2. To: (Receiving Organization) } \\
\text { Characterization Project } \\
\text { Operations }\end{array}$} & \multicolumn{4}{|c|}{$\begin{array}{l}\text { 3. From: (originating Organization) } \\
\text { Characterization Field } \\
\text { Engineering }\end{array}$} & \multicolumn{4}{|c|}{$\begin{array}{l}\text { 4. Related EDT No.: } \\
622127\end{array}$} \\
\hline \multicolumn{4}{|c|}{$\begin{array}{l}\text { 5. Proj./Prog./Dept./Div.: } \\
\text { Characterization }\end{array}$} & \multicolumn{4}{|c|}{$\begin{array}{l}\text { 6. Design Authority/ Design Agent/Cog. } \\
\text { Engr:: } \\
\text { E.J. Waldo }\end{array}$} & \multicolumn{4}{|c|}{$\begin{array}{l}\text { 7. Purchase order No.: } \\
\qquad N / A\end{array}$} \\
\hline \multirow{2}{*}{\multicolumn{8}{|c|}{$\begin{array}{l}\text { 8. originator Remarks: } \\
\text { This document provides results of the acceptance and } \\
\text { operability testing of RMCS exhauster C, as modified for } \\
\text { flammable gas tanks. }\end{array}$}} & \multicolumn{4}{|c|}{$\begin{array}{l}\text { 9. Equip./Component No.: } \\
\text { EX-C }\end{array}$} \\
\hline & & & & & & & & \multicolumn{4}{|c|}{$\begin{array}{c}\text { 10. System/Bldg./Facility: } \\
200 \mathrm{G}\end{array}$} \\
\hline \multirow{3}{*}{\multicolumn{4}{|c|}{ 11. Receiver Remarks: 11A. Design B }} & sel ine Document? & [] Yes & \multirow{3}{*}{\multicolumn{2}{|c|}{$[X]$ No }} & \multirow{2}{*}{\multicolumn{4}{|c|}{$\begin{array}{l}\text { 12. Major Assm. Dwg. No.: } \\
\text { H-2-829081, Rev. } 0 \\
\text { 13. Permit/Permit Application No.: } \\
\text { N/A }\end{array}$}} \\
\hline & & & & & & & & & & & \\
\hline & & & & & & & & \multicolumn{4}{|c|}{$\begin{array}{l}\text { 14. Required Response Date: } \\
\text { N/A }\end{array}$} \\
\hline \multicolumn{8}{|c|}{ 15. DATA TRANSMITTED } & (F) & \multirow[b]{2}{*}{\begin{tabular}{l|} 
(G) \\
Reason \\
for \\
Trans- \\
mittal
\end{tabular}} & (H) & (1) \\
\hline $\begin{array}{l}\text { (A) } \\
\text { Item } \\
\text { No. }\end{array}$ & \multicolumn{3}{|c|}{\begin{tabular}{l|l} 
(B) Document/Drawing No. & $\begin{array}{c}\text { Sheet } \\
\text { No. }\end{array}$
\end{tabular}} & $\begin{array}{l}\text { (D) } \\
\text { Rev. } \\
\text { No. }\end{array}$ & \multicolumn{3}{|c|}{$\begin{array}{l}\text { (E) Title or Description of Data } \\
\text { Transmitted }\end{array}$} & $\begin{array}{l}\text { Approval } \\
\text { Desig- } \\
\text { nator }\end{array}$ & & $\begin{array}{l}\text { Origi- } \\
\text { nator } \\
\text { Dispo- } \\
\text { sition }\end{array}$ & $\begin{array}{l}\text { Receiv- } \\
\text { or } \\
\text { Dispo- } \\
\text { sition }\end{array}$ \\
\hline 1 & \multicolumn{2}{|c|}{ HNF-1932 } & $\overline{A L L}$ & $\begin{array}{l}\text { Sys } \\
\text { Ope } \\
\text { Rep } \\
\text { Exh } \\
\text { Fla }\end{array}$ & \multicolumn{3}{|c|}{$\begin{array}{l}\text { System Acceptance and } \\
\text { Operability. Test } \\
\text { Report for the RMCS } \\
\text { Exhauster } c \text { on } \\
\text { Flammable Gas Tanks }\end{array}$} & \multirow[t]{2}{*}{$\mathrm{N} / \mathrm{A}$} & 1 & 1 & \\
\hline & & & & & & & & . & \\
\hline & & & & & & 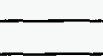 & & & \\
\hline & & & & & & & & & & & \\
\hline & & & & & & & & & & & \\
\hline 16. & & & & & KEY & & & & & & \\
\hline Appr & val Desig & nator (F) & Reass & in for Transmittal (G) & & & & Dispositior & $n(H) \&(I)$ & & \\
\hline $\begin{array}{l}\text { E, s, } 0 \\
\text { (see W } \\
\text { Sec.12 }\end{array}$ & $\begin{array}{l}\text { or N/A } \\
\text { (C-CM-3- }\end{array}$ & & $\begin{array}{ll}\text { Approval } & 4 . R \\
\text { ielease } & \text { 5. P } \\
\text { nformation } & \text { 6. D } \\
\end{array}$ & $\begin{array}{l}\text { oview } \\
\text { ost-Review } \\
\text { ist. (Receipt Acknow. R }\end{array}$ & Required) & & $\begin{array}{l}\text { proved } \\
\text { proved w/com } \\
\text { approved w/c }\end{array}$ & $\begin{array}{ll} & 4 \\
\text { mment } & 5 \\
\text { comment } & 6\end{array}$ & $\begin{array}{l}\text { Reviewed } \\
\text { Reviewed } \\
\text { Receipt a }\end{array}$ & $\begin{array}{l}\text { Ino/commer } \\
\text { i w/commen } \\
\text { cknowledge }\end{array}$ & \\
\hline & & & & $\begin{array}{l}\text { 17. SIGNAT } \\
\text { (See Approval Design }\end{array}$ & $\begin{array}{l}\text { URE/DISTRIBL } \\
\text { lator for requir }\end{array}$ & $\begin{array}{l}10 \mathrm{~N} \\
\mathrm{~d} \text { signat }\end{array}$ & & & & & \\
\hline $\begin{array}{l}\text { (G) } \\
\text { Rea- } \\
\text { son } \\
\end{array}$ & $\begin{array}{l}\text { (H) } \\
\text { Disp. }\end{array}$ & (J) Name & (K) Signature & (L) Date (M) MSIN & $\begin{array}{c}\text { (G) } \\
\text { Rea- } \\
\text { son }\end{array}$ & $\begin{array}{l}\text { (H) } \\
\text { Disp. }\end{array}$ & (J) Name & (K) Sig & gnature (1) & Date & MSIN \\
\hline 3 & & Design Authori & ity JR_Kriskc & vich & & & & & & & \\
\hline 3 & & Design Agent & JD Criddle & $57+1$ & & & & & & & \\
\hline 1 & 1 & Cog.Eng. EJ W & Waldo Gripy & 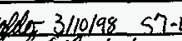 & & & & & & & \\
\hline 1 & 1 & Cog. Mgr. JS & schofield & $2+601 / 10 / 357-1$ & & & . & & & & \\
\hline 3 & & QA ML MCELIROY & & $57-0$ & & & & & & & \\
\hline 3 & & Safety JA Ran & inschau & $57 \cdot 0$ & & & & & & & \\
\hline 3 & & Operations TD & D Jarecki & $57-0$ & & & & & & & \\
\hline $\begin{array}{l}18 . \\
\text { E.J Wh } \\
\text { Signat } \\
\text { Siging }\end{array}$ & $\begin{array}{l}\text { Ido } \\
\text { Walde } \\
\text { re of EDT } \\
\text { or }\end{array}$ & $-\frac{3 / 10 / 98}{\text { Date }}$ & Authorized Repr & $\frac{3.10 .99}{\text { esentative }} \frac{\text { Date }}{\text { ganization }}$ & $\begin{array}{l}20 . \\
\text { J.S. Schotig } \\
\text { Defign Auth } \\
\text { Cognizant M }\end{array}$ & nager & $3 / 10 / 98$ & $\begin{array}{l}\text { 21. DOE AP } \\
\text { Ctrl. } \\
\text { [] Approve } \\
\text { [] Approve } \\
\text { [] Disappr }\end{array}$ & $\begin{array}{l}\text { PPROVAL } 6 \\
\text { No. } \\
\text { ed } \\
\text { ed } \mathrm{w} / \mathrm{comm} \\
\text { roved } \mathrm{w} / \mathrm{c}\end{array}$ & $\begin{array}{l}\text { if requir } \\
\text { nents } \\
\text { :orments }\end{array}$ & \\
\hline
\end{tabular}




\section{System Acceptance and Operability Test Report for the RMCS Exhauster C on Flammable Gas Tanks}

Eric J. WaT do

Lockheed Martin Hanford Company, Richland, WA 99352

U.S. Department of Energy Contract DE-AC06-96RL13200

EDT/ECN: 622141

Org Code: 74910

UC: 2070

B\&R Códe: EW3120074

Charge Code: $\mathrm{N} 4 \mathrm{H} 2 \mathrm{O}$

Total Pages: 33

Key Words: Rotary Mode Core Sampling, Exhauster, RMCS, Flammable Gas Tanks

Abstract: This test report documents the completion of acceptance and operability testing of the rotary mode core sampling (RMCS) exhauster $C$, as modified for use as a major stack (as defined by the Washington State Department of Health) on $f l$ ammable gas tanks.

TRADEMARK DISCLAIMER. Reference herein to any specific comercial product, process, or service by trade name, trademark, manufacturer, or otherwise, does not necessarity constitute or imply its endorsement, recommendation, or favoring by the United States Government or any agency. thereof or its contractors or subcontractors.

Printed in the United States of America. To obtain copies of this document, contact: Document Control Services, P.0. Box 950, Mailstop H6-08, Richland WA 99352, Phone (509) 372-2420;

Fax (509) 376-4989.
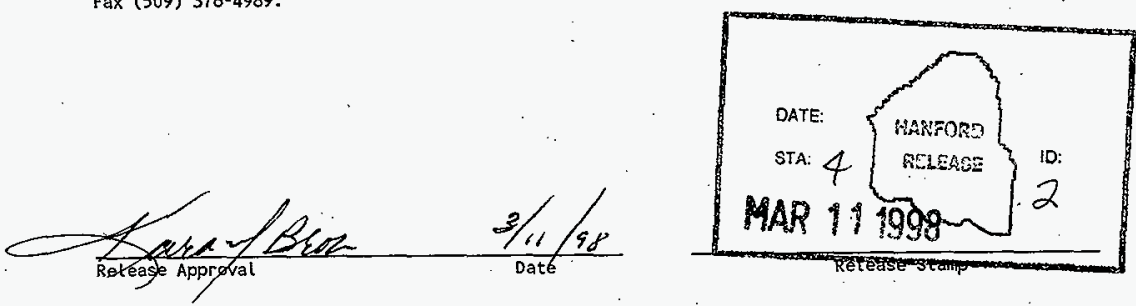

Approved for Public Release 
HNF-1932 REV. 0

SYSTEM ACCEPTANCE AND OPERABILITY TEST REPORT

FOR THE

RMCS EXHAUSTER C

ON FLAMIMABLE GAS TANKS

\author{
E. J. WALDO
}

CHARACTERIZATION FIELD ENGINEERING LOCKHEED MARTIN HANFORD COMPANY

MARCH, 1998 


\subsection{PURPOSE}

This test report documents the completion of acceptance and operability testing of the rotary mode core sampling (RMCS) Exhauster C, as modified for use as a major stack on flammable gas tanks. Previous flammable gas modification acceptance testing is documented in WHC-SD-WM-ETP-182, ReV 2.

\subsection{TEST RESULTS}

Testing was performed under work package ES-97-00021 during February, 1998. Attachment A contains the completed copy of HNF-1931 Rev 0 System Acceptance and Operability Testing for the RMCS Exhauster C on Flammable Gas Tanks. Sections 7.0 and 8.0 of the test procedure contain the completed test data. Section 9.0 contains the test equipment calibration data. Personnel involved with the performance of the test procedure are documented in section 10.0 .

\subsection{TEST VARIANCES}

The exceptions to this procedure are documented on page A-30 of Attachment A. AlT exceptions were satisfactorily resolved, as indicated by the approval initials for each item. No further action is necessary for resolution of these items.

\subsection{TEST SUMIMARY}

Acceptance and operability testing of the RMCS Exhauster C was successfully completed during February, 1998. All exceptions were satisfactorily resolved (page $A-30$ of Attachment $A$ ). Completion of the testing is documented on the "Test Completion Sign-0ff" sheet (page A-29 of Attachment A). 
HNF-1932 REV 0

ATTACHMENT A

SYSTEM ACCEPTANCE AND OPERABILITY TESTING

FOR THE

RMCS EXHAUSTER C

ON FLAMMABLE GAS TANKS

(HNF-1931 REV 0)

E. J. WALDO

CHARACTERIZATION FIELD ENGINEERING

LOCKHEED MARTIN HANFORD COMPANY

DECEMBER, 1997

A-1 


\section{TABLE OF CONTENTS}

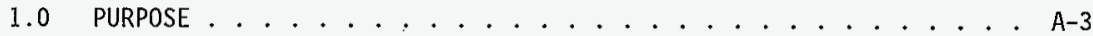

$2.0 \mathrm{SCOPE} \ldots \ldots \ldots \ldots \ldots \ldots$

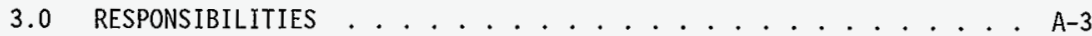

4.0 INFORMATION .................... . . . . . . .

4.1 TEST GUIDANCE $\ldots \ldots \ldots$. . . . . . . . . . . . A-5

4.2 TERMS AND DEFINITIONS ................. . . . . . . . . .

4.3 REFERENCES .................... . . . . . . . . . . . . .

4.4 SAFETY ISSUES . . . . . . . . . . . . . . . . A A-7

4.5 RADIATION AND CONTAMINATION CONTROL . . . . . . . . . A-7

4.6 QUALITY ASSURANCE . . . . . . . . . . . . . . . . . A-7

4.7 AUTOMATIC EXHAUSTER SYSTEM SHUTDOWNS . . . . . . . . A-8

4.8 EXHAUSTER COMMON FAULT ALARMS . . . . . . . . . . . A-8

4.9 ACCEPTANCE CRITERIA . . . . . . . . . . . . . A-8

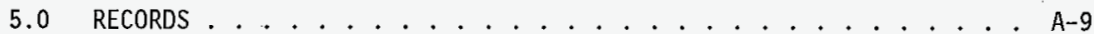

6.0 PREREQUISITES . . . . . . . . . . . . . . . . . . A-9

6.1 EQUIPMENT AND SUPPLIES ................ . A-9

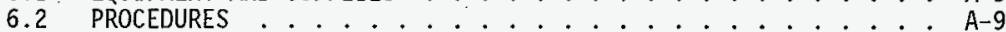

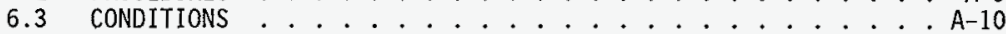

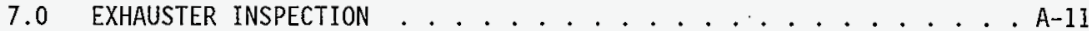

7.1 EXHAUSTER LABELING INSPECTION ............. A-11

7.2 PRESSURE DECAY TEST . . . . . . . . . . . A-15

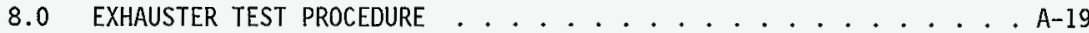

8.1 EXHAUSTER SETUP AND STARTUP . . . . . . . . . . . . A-19

8.2 DATA LOGGER OPERATION ................. . . . . . . . . . .

8.3 COMMON FAULT ALARMS . . . . . . . . . . . . . . . . A-21

8.4 UNATTENDED OPERATION INTERLOCK . . . . . . . . . . . . . . A-24

8.5 EXHAUSTER AUTOMATIC SHUTDOWNS . . . . . . . . . A-24

8.6 EXHAUSTER SHUTDOWN AND TAKEDOWN . . . . . . . . . . . A-26

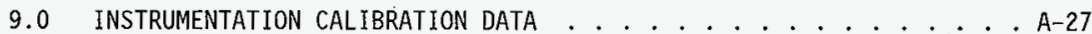

10.0 SIGNATURE LOG . . . . . . . . . . . . . . . A-28

11.0 TEST COMPLETION SIGN-OFF . . . . . . . . . . . . A-29 EXCEPTION / RESOLUTION DATA SHEET . . . . . . . . . . A-30 


\subsection{PURPOSE}

The purpose of this acceptance and operability procedure is to provide instructions for system acceptance and operability testing of the rotary mode. core sampling (RMCS) exhauster C, as modified for use as a major stack (as defined by the Washington State Department of Heaith) on flammable gas tanks. This testing fulfills the applicable requirements of HNF-SD-WM-ETP-230, Section 3.6 ; and HNF-PRO-446 (see section 4.3 of this document for complete references).

\subsection{SCOPE}

System acceptance and operability testing of the RMCS exhauster C will verify that system design requirements, as well as functional and operational requirements, have been met. Previous $f l$ ammable gas modification acceptance testing is documented in WHC-SD-WM-ETP-182, Rev 2. Testing will be completed in two phases. The first phase of testing (section 7) will involve a visual inspection of the exhauster labeling and a pressure decay test of the heater and HEPA filter housings. The second phase of testing (section 8) will involve operating the RMCS exhauster $C$ to demonstrate acceptable operation of systems modified for use on flammable gas tanks. Testing will primarily be conducted behind the 2704HV buiTding. Some portions of the testing may be conducted at a simulated tank farm environment at the "Rock Slinger" test site, located just south of U-Plant in the 200 West Area.

\subsection{RESPONSIBILITIES}

Safety, QA, Characterization Project Operations (CPO), Characterization Equipment Design (CED), Design Authority, and Characterization Field Engineering (CFE) shali approve this test procedure (hereafter referred to as the OTP), prior to its release. Responsibilities are as follows:

\section{Operations Test Director}

Responsible for the overail performance of the OTP. Responsible for the proper conduct of operations for the entire test site as well as al1 personnel involved in the testing. Ensures the execution of all testing activities are within the scope of the OTP. Exercises stop work authority for unsafe activities or activities not conforming to this OTP. Directs the overall conduct and sequencing of testing activities. Ensures configuration management is properly maintained. Directs actions to be taken to prevent injury to employees or damage to equipment. Acts through the core sampling PIC for the proper performance of all operations at the test site. Receives technical advice from CED and CFE engineers on system and equipment design parameters. Maintains cognizance of test exceptions as documented by the CFE Cognizant engineer and the resolution of same. Concurs with all changes and with the acceptability and reliability of the equipment by signing the OTP. 


\section{Core Sampling PIC}

Responsible for the assignment of personnel and directing the operation of the various systems. Controls configuration and access to the test area in order to maintain a safe environment. Aids the Cognizant Engineer in maintaining configuration control. Approves changes to the OTP in terms of operational steps or equipment configuration with concurrence of CED and CFE cognizant engineer and Operations Test Director. Conducts a pre-job safety meeting at the start of each shift during the performance of the OTP. Briefs the personnel on testing to be performed that day and associated hazards.

\section{CFE Cognizant Engineer}

Provides on site technical expertise and advice to the PIC and Test Director as required. Controls the sequence in which the OTP is conducted through the Test Director and with concurrence of CED. Maintains configuration control during testing: Approves any changes to the OTP. Notes exceptions to testing on the "Exception / Resolution Data Sheet." Resolves exceptions with the concurrence of CED, DA and the assigned Quality Engineer for those exceptions relating to items which initially required Quality verification. Concurs with the acceptability and reliability by signing the OTP.

\section{Design Authority (DA)}

Approves any changes to the OTP. Approves test procedure and test report. Concurrence resolution of exceptions. Concurs with the acceptability and reliability by signing the OTP.

\section{Characterization Equipment Design (CED)}

Provides on site technical expertise and advice to the PIC and Test Director as required. Advises $\mathrm{Cog}$. Engineer and Test director on equipment capabilities, recommended test sequence changes, and test requirements. Responsible for issuing any Engineering Change Notices (ECN's) required to support maintaining configuration control during testing. Approves any changes to the OTP. Responsible for obtaining additional support from engineering. Reviews and approves test procedure and test report. Resolves any design or project related deficiencies.

\section{Core Sampling Operations Management}

Responsible through the Operations Test Director for the overall testing program. Reviews and approves test procedure. Ensures effective safety meeting is held prior to test start. Monitors testing to extent approval may be given for satisfactory equipment operability and reliability.

\section{Core Sampling Operators}

Conducts testing according to the OTP procedure as directed by the operations PIC. Notifies the PIC of concerns, exceptions and off-normat conditions during testing. 


\section{Quality Assurance}

Reviews and approves test procedure to assure compliance with appropriate regulations. Resolves exceptions requiring quality verification jointly with CFE Cognizant Engineer. Quality verification of exceptions is only necessary for those exceptions relating to items which initialiy required Quality verification or any changes to acceptance criteria.

\section{Safety}

Reviews and approves test procedure to assure compliance with applicable regulations. Monitors testing as appropriate.

\section{CPO Radiological Control}

Supports testing according to the OTP procedure as directed by the Operations PIC. Notifies the PIC of concerns, exceptions and off-normal conditions during testing. Ensures work performed is within the scope of the applicable Radiological Work Permit (RWP).

\subsection{INFORMATION}

\subsection{TEST GUIDANCE}

Authorization for the implementation of this document is controlled by the associated Engineering Data Transmittal. Approval indicates that the testing called out in this procedure will verify the required performance of the equipment and provide the required protection of personne1.

Acceptance and operability testing will be completed in two phases. The first phase of testing (section 7) will involve a visual inspection of the exhauster labeling and a pressure decay test of the heater and HEPA filter housings. The second phase of testing (section 8 ) will involve operating the RMCS exhauster $C$ to demonstrate acceptable operation of systems modified for use on flammable gas tanks, and all common fault alarms and shutdown interlocks.

Initiai instrument calibrations shall be conducted prior to Operability testing. Calibrations will not be reconfirmed for OTP testing as no advantage will be realized.

Discrepancies, deviations, or irregularities involving the test procedure or equipment performance are to be noted, as they occur, on the "Exception / Resolution Data Sheet". An exception number shail be noted in the procedure margin, next to the related test section or step. These exceptions shall be jointly resolved between the Cog. Engineer, the Design Authority, the Test Director, and the assigned Quality Assurance Representative. Quality verification of exceptions is only necessary for those exceptions relating to items which initially required Quality verification. A11 resolutions to the exceptions must be agreed upon by the responsible personnel, documented on the exception list, and initialed. Hand written exception sheets may be replaced, if replacement sheets are initialed. 
No testing shall be done which directly involves faulty equipment.

However, at the discretion of the Cog Engineer and with the concurrence of the Test Director, CED and the PIC, tests may proceed on equipment which is not affected by faulty equipment. Any test exceptions caused by equipment fairure not associated, directly or indirectly, with the system modifications for flammable gas tank sampling, will be dispositioned as "general maintenance" on the Exception / Resolution Data Sheet.

If, due to testing circumstances, on-site modifications of the test procedures are warranted, written changes ("redlines") may be made by the core sampling PIC with the written approval (initialing in the left margin) of the Test Director, Cog Engineer and CED. These changes must a] so be documented on the Exception / Resolution Data Sheet prior to test completion sign-off. Amendments shall be per instructions in HNFPR0-446, "Testing Requirements".

Operating procedures, written for RMCS operations in flammable gas tanks, are referenced for use as directional information within this OTP. Sections and steps in those procedures may be worked out of sequence or skipped if needed to support this testing activity. Approval by the PIC, Test Director or Cog engineer of these changes is required.

\subsection{TERMS AND DEFINITIONS}

$\begin{array}{ll}\text { CE or COG } & \text { - Core Sampling Cognizant Engineer } \\ \text { CED } & \text { - Characterization Equipment Design } \\ \text { CFE } & \text { - Characterization Field Engineering } \\ \text { CPO } & \text { - Characterization Project Operations } \\ \text { DA } & \text { - Design Authority } \\ \text { DT } & \text { - Electrical Power Distribution Trailer } \\ \text { FGWL } & \text { - Flammable Gas Watch List } \\ \text { HEPA } & \text { - High Efficiency Particulate Air } \\ \text { OP } & \text { - Operator } \\ \text { OTP } & \text { - Operability Test Procedure } \\ \text { OTR } & \text { - Operability Test Report } \\ \text { PIC } & \text { - Person In Charge } \\ \text { QA } & \text { - Quality Assurance } \\ \text { QC } & \text { - Quality Control (inspection) } \\ \text { RMCS } & \text { - Rotary Mode Core Sampling } \\ \text { RWP } & \text { - Radiological Work Permit } \\ \text { SCFM } & \text { - Standard Cubic Feet per Minute } \\ \text { TD } & \text { - Test Director } \\ \text { TWRS } & \text { - Tank Waste Remediation System } \\ \text { VAC } & \text { - Volts, Alternating Current } \\ \text { VFD } & \text { - Variable Frequency Drive } \\ \end{array}$


HNF-1932 REV 0

\subsection{REFERENCES}

HNF-SD-WM-ETP-230, Rev. 2 Engineering Task P7an for the Field Deployment of Two Core Sampling Exhausters Utilizing Basis for Interim Operation Technical Specification Requirements

HNF-SD-WM-FDC-025, Rev. 2 Functional Design Criteria for the Rotary Mode Core Sampling Exhauster.

HNF-SD-WM-OTP-223, Rev. 0 System Acceptance and Operability Testing for Rotary Mode Core Sampling in Flammable Gas Tanks

WHC-SD-WM-ETP-182, Rev. 2 Engineering Task Plan for the Rotary Mode Cores Sampling Exhauster Flammable Gas Upgrades

WHC-SD-WM-SAD-035, Rev. Ob

Safety Assessment of RMCS in F7ammable Gas Single She 71 Tanks

WHC-SD-WM-TSR-006, Rev. 0

Tank Waste Remediation System Technical Safety Requirements

HNF-PR0-446

Testing Requirements

HNF-IP-0842

TWRS Administration

\subsection{SAFETY ISSUES}

To reduce the possibility of injury, all persons in the vicinity of the test equipment must be made aware of the following concerns:

Harning - Personal protective equipment. should be used during testing, such as safety glasses, gloves, hearing protection and safety shoes, when appropriate.

Warning - Be aware of tripping hazards such as cables and duct work.

\subsection{RADIATION AND CONTAMINATION CONTROL}

All testing will be non-radioactive. Any work performed at the "Rock Slinger" test site must comply with the requirements listed in RWP issued for testing activities at that site.

\subsection{QUALITY ASSURANCE}

Quality Assurance shall approve this test procedure prior to its release. A Quality Control representative shall verify all steps requiring $Q C$ verification during testing or any changes to acceptance criteria. 


\subsection{AUTOMATIC EXHAUSTER SYSTEM SHUTDOWNS}

The exhauster is designed to shut down automatically when any of the following conditions occur:

- Tank pressure falls below -3 inches water gauge (wg).

- Exhauster stack flow exceeds 250 scfm for 5 minutes or falls below $150 \mathrm{scfm}$.

- Total pressure drop across the HEPA filters exceeds 5.5 inches wg.

- Common Fault Alarm is received when exhauster is in UNATTENDED OPERATION mode.

All of these shutdowns will be forced to occur during performance of this test procedure.

\subsection{EXHAUSTER COMMON FAULT ALARMS}

The exhauster is equipped with six alarms which will trigger a common fault alarm strobe on the top of monitoring cabinet. Upon operator acknowledgement the alarm strobe will extinguish until another new alarm is received. These alarms are generated by the data logger which monitors exhauster functions. In the event of a data logger system error, the alarm strobe will become lit. A system error cannot be acknowledged and wil] require the alarming condition to be rectified in order to extinguish the alarm beacon. The exhauster conditions which will activate the common fault alarm light are listed below:

- HEPA filter inlet humidity above $70 \%$.

- HEPA filter inlet temperature above $150^{\circ} \mathrm{F}$.

- Record sample flow variance above $\pm 10 \%$.

- Beta sample flow variance above $\pm 10 \%$.

- Beta CAM high radiation alarm.

- Beta CAM failure alarm.

A11 of these alarms will be forced to occur during performance of this test procedure.

\subsection{ACCEPTANCE CRITERIA}

The acceptance criteria for this OTP is based on operability and reliability of the exhauster when used as if it were in the field. Each step shall be evaluated and signed off by the cognizant engineer and operations to verify that the exhauster is acceptable for field use. Acceptable reliability based on this testing shall be determined by the judgement of the cognizant engineer and the operation manager. The acceptance of the overall reliability of the system shall be documented by signatures on the Test Completion Sign-Off Sheet. 


\subsection{RECORDS}

Pertinent operating conditions will be documented where requested in this OTP. Records for the testing of the exhauster will be recorded within the procedure. The operator, and other personnel requested to do so, will initial in the space provided in the left hand margin upon satisfactory completion of the designated tasks.

All test data will be released, as an Operability Test Report, after the conclusion of OTP testing.

\subsection{PREREQUISITES}

\subsection{EQUIPMENT AND SUPPLIES}

The following equipment and supplies will be required during testing:

- RMCS exhauster $C$ and associated equipment.

- Portable electric generator.

- Electrical power distribution trailer.

- Stop Watch.

- Fluke model 701 test device, or equivalent.

- Air Neutronics model MP205 Digital Manometer, or equivalent.

- Hand operated pressure/vacuum pump and associated tubing.

- Test pressure flange for heater inlet.

- Pressure and vacuum sources for pressure decay test.

\subsection{PROCEDURES}

The following procedures will be required during testing:

- T0-020-451, Setup and Takedown of Core Sample Systems

- T0-020-825, Katolight Model D200FRJ4 Standby Power System Operation

- T0-020-900, Onan 150DGFA Generator Set Operation

- T0-060-347, Operate RMCS Exhauster on Passively Ventilated Tanks

- 6-TF-155T, Core Sampling Exhauster 296-P-34 Air Flow Test

- 6-TF-156PC, Core Sampling Exhauster 296-P-34 HEPA FiTter Aerosol Test 


\subsection{CONDITIONS}

The following conditions must be signed off as complete prior to the beginning of exhauster testing (Section 8 ):

- A Job Hazard Analysis has been performed.

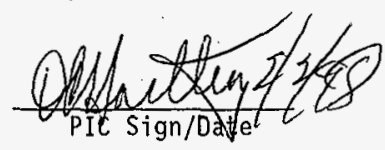

- Calibrations and PM's are current and complete prior to testing of affected equipment.

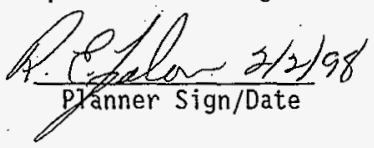

- All work packages for instaliation/functional check of flammable gas and major stack modifications are field work complete prior to related testing.

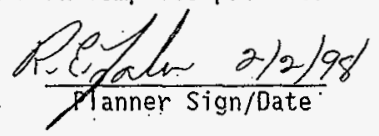




\subsection{EXHAUSTER INSPECTION}

\subsection{EXHAUSTER LABELING INSPECTION}

7.1.1 VERIFY the exhauster labels called out in the following table are present.

\begin{tabular}{|c|c|c|c|}
\hline (vongoneris & Descidotion & 106 & 11. 0 \\
\hline & Inlet End of Exhau & & \\
\hline VTP-HTR-2203C & GLYCOL TANK HEATER. & हो & $\$ 0$ \\
\hline VTP-TK-2201C & GLYCOL EXPANSION TANK & eft & $2 Q$ \\
\hline$V T P-P-2204 C$ & GLYCOL PUMP & 舟安 & 12 \\
\hline VTP-P-2205C & SEAL POT PUMP & 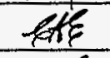 & Q1 \\
\hline VTP-DS-2202C & HTR DISCONNECT $480 \mathrm{~V} 3 \mathrm{PH}$ & 绝 & De \\
\hline VTP-PB-2211C & SEAL POT PMP SW & bft & $Q$ \\
\hline VTP-HS-2201C & HEATER PWR SW & $\operatorname{lt} 6$ & $\mathrm{Ne}$ \\
\hline VTP-IL-2201C & HEATER ON & बह & De \\
\hline VTP-TL-2202C & PUMP ON & धाद & Q \\
\hline$V T P-I L-2203 C$ & LOW HTR FLUID & हो & 82 \\
\hline VTP-SG-2201C & SEAL POT LVL & दाध & 10 \\
\hline VTP-SG-2202C & HTR FLUID LVL & 616 & 20 \\
\hline$V T P-V-2232 C$ & HEPA 2 COND DRN VLV & $\operatorname{le}$ & Le \\
\hline$V T P-V-2233 C$ & HEPA 1 COND DRN VLV & G店 & de \\
\hline$V T P-V-2234 C$ & PREFILTER COND DRN VLV & - & Q \\
\hline VTP-V-2235C & STACK COND DRN VLV & ets & L \\
\hline VTP-V-2236C & HTR COND DRN VLV & lete & 2 \\
\hline VTP-V-2258C & SEAL POT FUNNEL VLV & $\mathscr{G}$ & (2) \\
\hline VTP-V-2259C & HEATER FLD OUT VLV & Cot & DQ \\
\hline$V T P-V-2260 C$ & SEAL POT OUT VLV & G6 & M \\
\hline VTP-TE-2203C & HEPA FLT TEMP PROBE & tet & 2 \\
\hline & FILTER TRAIN SIDE OF & & \\
\hline VTP-HTR-2202C & FLT SYS INLET HTR & ef & $\mathrm{PQ}$ \\
\hline VTP-HUM-2201C & HEPA FLT HUMIDITY PRB & 67 & $\$ 2 \%$ \\
\hline VTP-V-222.8C & FLT BANK INLET ISO VLV & $6+8$ & Re \\
\hline
\end{tabular}




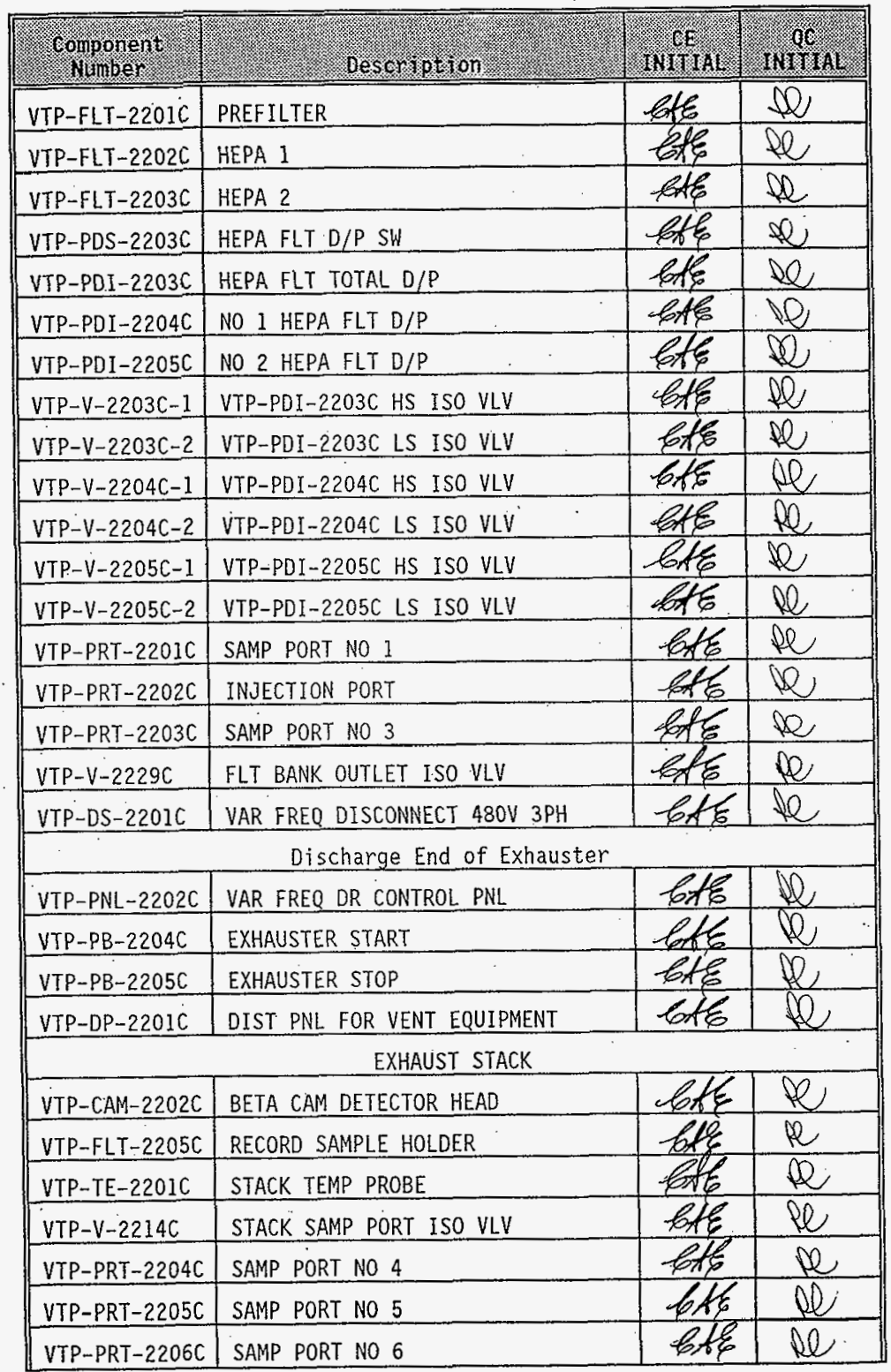


HNF-1932 REV 0

\begin{tabular}{|c|c|c|c|}
\hline $\begin{array}{l}\text { Component } \\
\text { Number }\end{array}$ & Descriction & 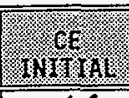 & 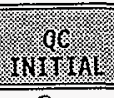 \\
\hline VTP-PRT-2207C & SAMP PORT NO 7 & left & $Q$ \\
\hline \multicolumn{4}{|c|}{ Air Monitor Cabinet } \\
\hline VTP-PB-2201C. & VAC PUMP START SW & $-6+6$ & PQ \\
\hline VTP-PB-2202C & SWAP VAC PUMP & CtE & $\mathbb{Q}$ \\
\hline VTP-PB-2203C & VAC PUMP RESET SW & $6+6$ & Q \\
\hline VTP-FIC-2206C & STACK FLOW CONTROLLER & Cote & Q \\
\hline VTP-SS-2204C & AIR COND NO 1 PWR SW & $6+6$ & Q \\
\hline VTP-V-2211C & RECORD - SAMP FCV INLET ISO VLV & E,fe & Q \\
\hline VTP-V-2212C & CAM SAMPLE FCV INLET ISO VLV & b+te & QQ \\
\hline VTP-FCV-2202C & RECORD FLOW CONT VLV & 6fe & Q \\
\hline VTP-FCV-2204C & CAM FLOW CONT VLV & eff & W \\
\hline VTP-V-2217C & RECORD SAMP FCV OUTLET ISO VLV & Ext & Q \\
\hline$V T P-V-2218 C$ & CAM SAMPLE FCV OUTLET ISO VLV & bte & R \\
\hline VTP-TE-2202C & SAMPLE TEMP PROBE & $6+8$ & Q \\
\hline VTP-PCV-2217C & SAMP PMP SUCT REG VLV & bxe & W \\
\hline VTP-PI-2206 & MANIFOLD VACUUM & E, & Re \\
\hline VTP-MOV-2215C & VAC PUMP INLET ISO VLV & efte & Q \\
\hline VTP-MOV-2216C & VAC PUMP OUTLET ISO VLV & $\cot 8$ & Pl \\
\hline VTP-P-2201C & PUMP 1 & GfE & QQ \\
\hline VTP-P-2202C & PUMP 2 & exte & Q \\
\hline VTP-PS-2207C & PP1 PRESS SWITCH & bts & M \\
\hline VTP-PS-2208C & PP2 PRESS SWITCH & $6+8$ & $\mathrm{Ne}$ \\
\hline VTP-SS-2206C & VAC Pp CONT CKT PWR SW & $\cot 6$ & p \\
\hline VTP-FT-2201C & STACK FLO XMITTER & toff & $\mathrm{BO}$ \\
\hline VTP-FT-2202C & RECORD FLO XMITTER & tete & D \\
\hline VTP-FT-2204C & CAM FLO XMITTER & $\operatorname{lox} \varepsilon$ & QD \\
\hline VTP-PIT-2205C & SAMP SYS PRES XMITTER & C & Q \\
\hline VTP-SS-2208C & AUTO SHUT DOWN BYP SW & $6+\varepsilon$ & Q \\
\hline VTP-SS-2207C & FCV CKT PWR SW & $6+6$ & 10 \\
\hline VTP-SS-2211C & SAMP FLO INST & Exts & Q \\
\hline VTP-SS-2210C & MONITORING EQUIP PWR SW & bot & $\mathrm{NO}$ \\
\hline
\end{tabular}




$$
D I-H
$$

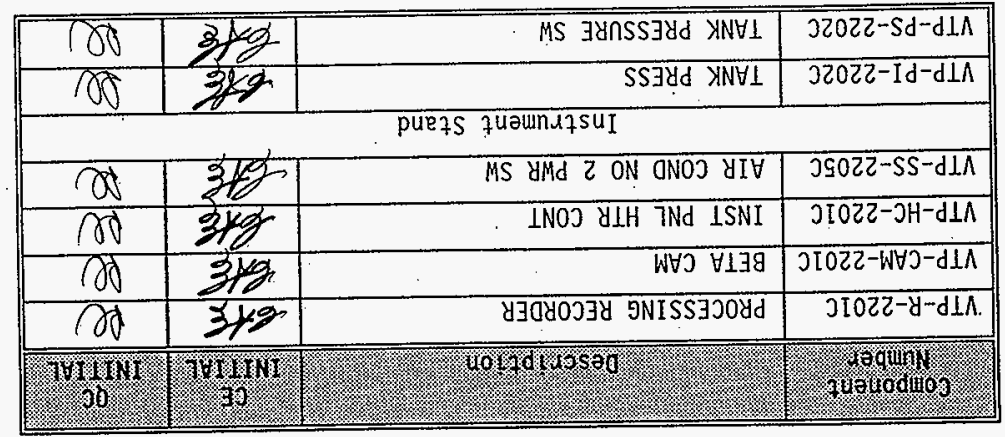




\subsection{PRESSURE DECAY TEST}

oP/CEZ/EJW 7.2.1 Maintenance INSTALL the test pressure flange with a neoprene gasket to the heater housing inlet.

OP/CB I EJW 7.2.2 Maintenance TORQUE the test pressure flange bolts to $30(25-35)$ ft-1bs.

OP/CE MEL EJW 7.2.3 ENSURE that the following valves are CLOSED:

$\checkmark$ VTP-V-2232C HEPA 2 COND DRN VLV

$\checkmark$ VTP-V-2233C HEPA 1 COND DRN VLV

$\checkmark$ VTP-V-2234C PREFILTER COND DRN VLV

$\checkmark$ VTP-V-2236C HTR COND DRN VLV

$\checkmark$ VTP-V-2204C-1 VTP-PDI-2204C HS ISO VLV

$\sqrt{V T P-V-2204 C-2}$ VTP-PDI-2204C LS ISO VLV

$\checkmark$ VTP-V-2203C-1 VTP-PDI-2203C HS ISO VLV

$\checkmark$ VTP-V-2203C-2 VTP-PDI-2203C LS ISO VLV

VTP-V-2205C-1 VTP-PDI-2205C HS ISO VIV

$\checkmark$ VTP-V-2205C-2 VTP-PDI-2205C LS ISO VLV

$\checkmark$ VTP-V-2229C FLT BANK OUTLET ISO VL $\bar{V}$

OP/CE MPCEJW 7.2.4 ENSURE VTP-V-2228C FLT BANK INLET ISO VLV is OPEN.

OPICE ZZE EJW 7.2.5 Instrument Technician INSTALL a digitai manometer to the test pressure flange.

OPICE ZIEJW $\quad 7.2 .6$

INSTALL an air pressure source to the test pressure flange.

OPICE 7 IEIW 7.2 .7 PRESSURIZE the housings to $12 \pm 2$ in. w.g..

OPICE IEJW 7.2.8 LOCATE Teaks (using a suitable bubble solution) AND SEAL as practical. opscegh EJW 7.2.9 $\begin{aligned} & \text { DISCONNECT the air pressure source from the test } \\ & \text { pressure flange. }\end{aligned}$

OPICE Zf IEZW 7.2.10 SLOWLY RELIEVE pressure from the housings.

OPICE 32 EJW 7.2.11 Instrument Technician REMOVE thermocouple wires from VTP-TE-2203C REPA FLT TEMP PROBE.

OPICEZIEJW 7.2.12 Instrument Technician CONNECT type $K$ thermocouple wire and reading device to terminals on VTP-TE-2203C HEPA FLT TEMP PROBE.

OPICEYIIEJW 7.2.13 CONNECT a vacuum source to the test pressure flange.

OPICE ZIEJW 7.2.14 DECREASE the heater/fi]ter train housing internal

pressure to $-26 \pm 2$ in. W.g.. 
OPICEZIEJW 7.2.15 MAINTAIN constant pressure (-26 \pm 2 in. w.g.) until the housing temperature remains constant within \pm 1.0 :F for a minimum of 10 minutes.

OPICE 2 AEJW 7.2.16 ISOLATE the vacuum source from the filter housing AND DISCONNECT the vacuum source from the test pressure flange.

NOTE: Barometric pressure readings in the following step may be obtained by calling the Hanford weather station (373-2716). only initial (0 min.) and final (15 min.) barometric pressure readings are required.

oP/cEIac B2EJWG 7.2.17 START stopwatch AND

RECORD data requested into the table below at one minute intervals.

\begin{tabular}{|c|c|c|c|}
\hline H NuTe & houstro poessune & 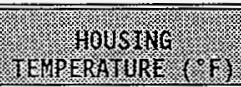 & 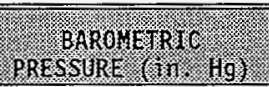 \\
\hline 0 & $-25,20$ & 39.8 & 28,753 \\
\hline 1 & -25.20 & 39.8 & \\
\hline 2 & $-25,20$ & 39.8 & \\
\hline 3 & $=25.19$ & 39.8 & \\
\hline 4 & -25.18 & 39.8 & \\
\hline 5 & -25.15 & 39.8 & \\
\hline 6 & -25.13 & 39.8 & \\
\hline 7 & -25.09 & 39.8 & \\
\hline 8 & -25.08 & 39.8 & \\
\hline 9 & -25.07 & 39.8 & \\
\hline 10 & -25.07 & 39.8 & \\
\hline 11 & -25.07 & 39.8 & \\
\hline 12 & -25.07 & 39.8 & \\
\hline 13 & $=25.09$ & 39.8 & \\
\hline 14 & -25.09 & 39.8 & \\
\hline 15 & -25.09 & 39,8 & 28.713 \\
\hline
\end{tabular}




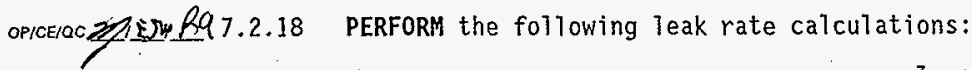

$V=$ Volume of housings to be pressurized $=36.4 \mathrm{ft}^{3}$

SÁV = Specified Acceptance Value $=0.0182 \mathrm{cfm}(3 \%$ of housing volume per hour).

$R A=$ Gas Constant for air $=53.35$

$\Delta t=$ elapsed time of test $=15 \mathrm{~min}$.

$Q=$ Average leak rate of housing in $\mathrm{cm}$.

$P_{f m}=$ Finat manometer pressure $P_{i m}=$ Initial manometer pressure $P_{f B}=$ Final barometric press. $P_{i B}=$ Initial barometric press .

Finish Temp. $\left({ }^{\circ} \mathrm{F}\right) \ldots 39.8+459.7=T_{f}=\underline{49}+5$

Start Temp. $\left({ }^{\circ} \mathrm{F}\right) \underline{39.8}+459.7=\mathrm{T}_{i}=499.5$

$P_{f}=P_{f m}=25.09 \times 5.204+P_{f B}-28.713 \times 70.73$

$P_{f}=-130.57+2,030.87$

$P_{f}=1,900,30$

$P_{i}=P_{i m}-25.20 \times 5.204+P_{i 8}-28.753 \times 70.73$

$P_{i}=-131,14+2,033,70$

$P_{i}=1,902,56$

$\dot{Q}=\left[\left(P_{f} / T_{f}\right)-\left(P_{i} / T_{i}\right)\right] \times[V /(R A \times \Lambda T \times 0.075)]$

$Q=\left[\left(P_{f} / T_{f}\right)-\left(P_{i} / T_{i}\right)\right] \times[36.4 /(53.35 \times 15 \times 0.075)]$

$Q=\left[\left(P_{f} / T_{f}\right)-\left(P_{i} / T_{j}\right)\right] \times 0.6065$

$P_{f} 1,900,30 / T_{f}-499,5=3.804$

$P_{i-1,902.56} / T_{i}-499.5=3.809$

$\dot{Q}=(3.804-3.809) \times 0.6065$

$Q=-.005 \times 0.6065$

$Q=-.003 \quad \mathrm{cfm} \quad$ SAV $=0.0182 \mathrm{cfm}$

OPICEIOC $P$ IEJW $R Q$ Q 7.2 .19 VERIFY that $Q<$ SAV.

OP/CEY 7.2 .20 SLOWLY RETURN housings to atmospheric pressure.

OPICEZIESW 7.2.21 REMOVE al1 test equipment. 
OPICEYAEJW

OPICE ZZYESW

OP/CE ZZLESW
7.2.22 Instrument Technician REPLACE thermocouple wires to VTP-TE-2203C HEPA FLT TEMP PROBE.

7.2.23 OPEN the following valves:

- VTP-V-2204C-1 VTP-PDI-2204C HS ISO VLV

- VTP-V-2204C-2 VTP-PDI-2204C LS ISO VLV

- VTP-V-2203C-1 VTP-PDI-2203C HS ISO VLV

- VTP-V-2203C-2 VTP-PDI-2203C LS ISO VLV

- VTP-V-2205C-1 VTP-PDI-2205C HS ISO VLV

- VTP-V-2205C-2 VTP-PDI-2205C LS ISO VLV

7.2.24 CLOSE VTP-V-2228C FLT BANK INLET ISO VLV. 


\subsection{EXHAUSTER TEST PROCEDURE}

\subsection{EXHAUSTER SETUP AND STARTUP}

OPICEUUE EJW

8.1 .1

SETUP exhauster per applicable portions of sections $5.3,5.4$, and 5.5 of procedure T0-020-451.

OPICE MूEJW

8.1 .2

PERFORM section 5.6 of TO-020 -451 AND

VERIFY that the following tasks are successfully completed.

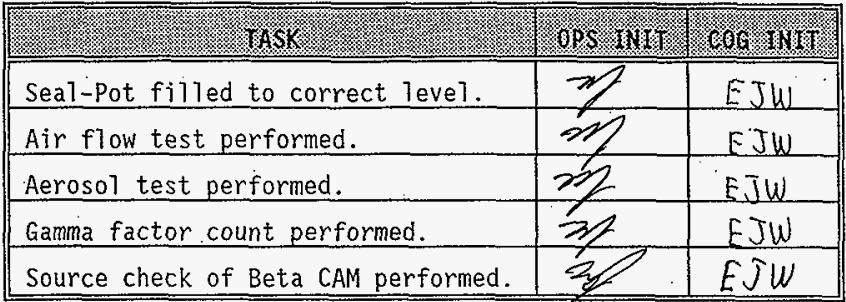

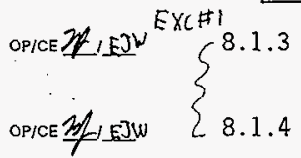

PLACE exhauster into STANDBY MODE per procedure T0-060-347, Section 5:25.1

PLACE exhauster into ATTENDED OPERATION MODE per procedure TO-060-347, Section $-5.35,2$,

\subsection{DATA LOGGER OPERATION}

NOTE: The data logger's initial display mode is PLANT SUMMARY. All exhauster information is contained within 4 groups, titled OPERATION STATUS; EQUIPMENT STATUS, RUN TIME LOG, and COMMON FAULT ALARMS. In the MULTI-GROUP display mode, all exhauster channel values can be viewed simultaneously. Channel numbers are displayed on the chart printout and on the ALARM SUMMARY disp]ay screen, but not on the MULTI-GROUP display screen. 'Channels on the MULTI-GROUP display screen are identified by a descriptive tag and units.

OPICE ZR EJIV 8.2 .1

ENSURE exhauster is in ATTENDED OPERATION mode, and that the exhaust fan has run for at least 5 minutes before proceeding. 


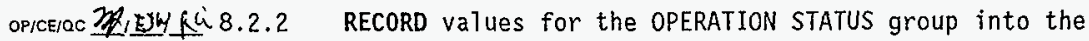
$E \times C+2$ following table AND

VERIFY values are acceptable.

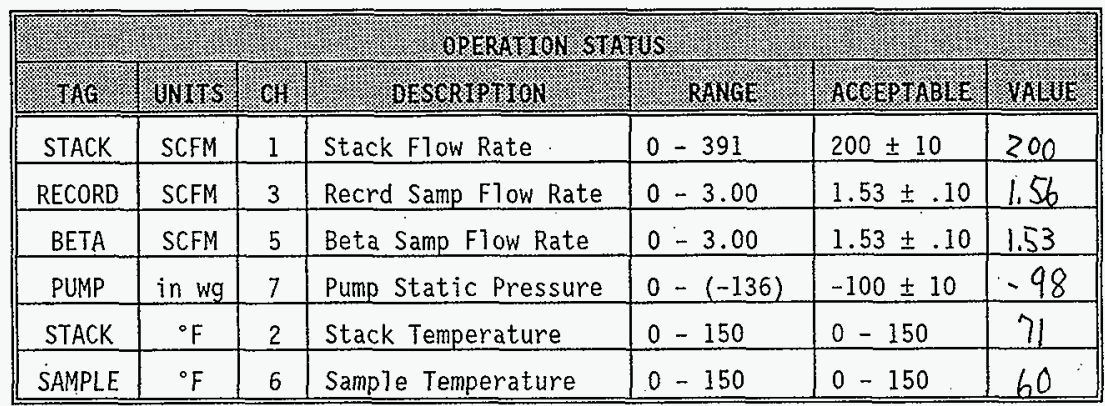

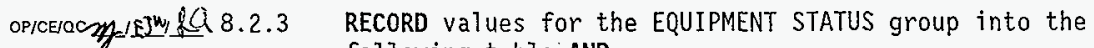
following table AND

VERIFY values are acceptable.

\begin{tabular}{|c|c|c|c|c|c|}
\hline . & 要 & Beseriptian & 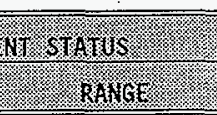 & ACcerpirible: & $\sqrt{6451}$ \\
\hline STACK & 14 & Stack Fan $(0 n-0 f f)$ & ON, OFF & $\mathrm{ON}$ & $O W$ \\
\hline PUMP P1 & 15 & Pump P1 (On-Off) & ON, OFF & \multirow{2}{*}{$\begin{array}{l}\text { One pump ON, } \\
\text { and other } \\
\text { pump OFF }\end{array}$} & OFF \\
\hline PUMP P2 & 18 & Pump P2 (0n-Off) & ON, OFF & & $O N$ \\
\hline PMPFAIL & 19 & Pump Fail & NORMAL, FAILED & NORMAL & NORMAL \\
\hline HEATER & 22 & Heater (On-off) & ON, OFF & ON & $O N$ \\
\hline
\end{tabular}




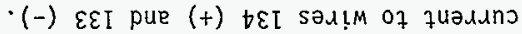

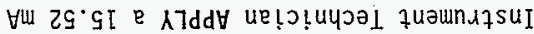

- qautqes

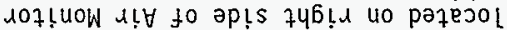
xoq uolqounc Gu!d!M pla!t uodt $t \varepsilon$ l pue

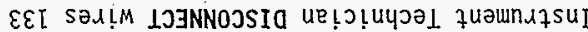

$[\cdot \tau \cdot \varepsilon \cdot 8$

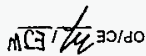

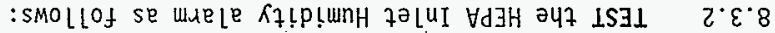

- бu!paazodd alofaq

səznuiul $s$ 7seal ze lof und sey uef 7sneyxa a47 7ey7

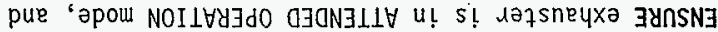

$[\cdot \varepsilon \cdot 8$ Mf]

- pasealo sey uo!f!puos mue

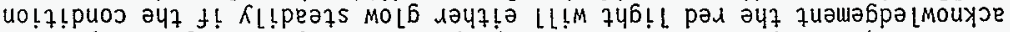

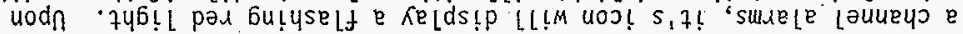

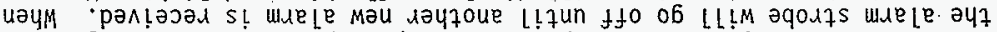

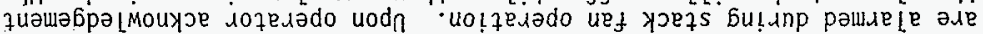

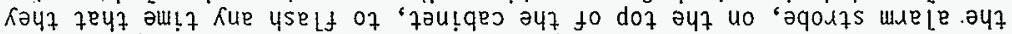

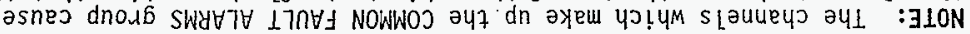

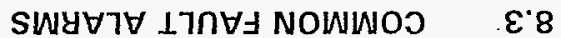

\begin{tabular}{|c|c|c|c|c|c|c|}
\hline THWOON & TVWYON & $\begin{array}{l}\text { 0J7IVJ } \\
\text { "TVWYON }\end{array}$ & Lted WHJ eqag & $\varepsilon[$ & $\forall / N$ & $7 I \forall \pm W \forall J$ \\
\hline 74wyon & THWYON & $\begin{array}{l}\text { aJWYYר } \\
\text { "7 WWYON }\end{array}$ & mue L $\forall$ pey $W \forall J$ eqəg & ZI & $\forall / \dot{N}$ & O甘d W W J \\
\hline ᄀ $\forall N$ บON & TVWYON & $\begin{array}{l}\text { OJWYYTH } \\
\text { "TVWYON }\end{array}$ & den Molf aldues eqag & $\nabla \varepsilon$ & $\forall / N$ & $\forall \forall \wedge \forall \perp \exists g$ \\
\hline THWron & TGWYON & 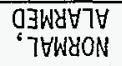 & URA MOLA durs piosay & IE & $\forall / N$ & $8 \forall \Lambda ~ כ \exists y$ \\
\hline 08 & $0 \mathcal{G}[-0$ & $002-0$ & düI $7 \partial\left[I_{I} \quad \forall d \exists H\right.$ & $b 2$ & \pm 0 & dW 1 \\
\hline 91 & $0 L-0$ & $00[-0$ & 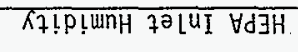 & $\varepsilon 2$ & $\%$ & JIWnH \\
\hline 310 & 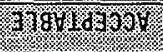 & 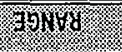 & NoY Wrogs & 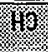 & SU, & 2010 \\
\hline
\end{tabular}

-

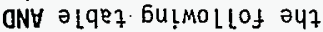

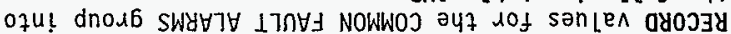


HNF-1932 REV 0

OPICEOCZ EWIRG

8.3.2.3 RECORD value displayed for HUMID in COMMON FAULT ALARMS group AND

VERIFY that the value is acceptable.

\begin{tabular}{|c|c|c|c|c|c|}
\hline$\sqrt{14}$ & GNG ISS & ci: & oescrabrion & 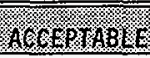 & 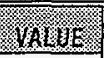 \\
\hline HUMID & $\%$ & 23 & HEPA Inlet. Humidity & $70-74$ & 72 \\
\hline
\end{tabular}

NOTE: The HEPA inlet humidity common fault alarm has a 5 minute delay.

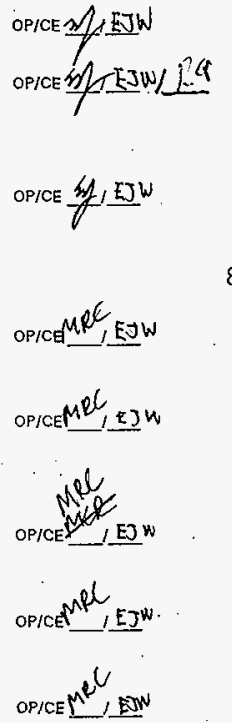

\section{3 .3}

8.3.2.4 WAIT 5 minutes before proceeding.
8.3.2.5 VERIFY that the external alarm strobe and the HUMID icon with in the COMMON FAULT ALARMS group are flashing.
8.3.2.6 Instrument Technician RECONNECT wire 133 to terminal 5 and wire 134 to terminal 6 .

ACKNOWLEDGE alarm(s) on the data logger as follows:

8.3.3.1 PRESS Common FauTt ATarms group anywhere in box. Outside of box will turn yellow.
8.3.3.2 PRESS gO TO key. Common Fault. Alarms group will occupy entire screen.

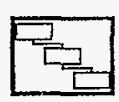
8.3.3.3 PRESS ACK key located at top right of screen.

8.3.3.4 VERIFY that external alarm strobe has turned OFF.

8.3.3.5 PRESS MULTI-GROUP key to return screen to normal appearance.

8.3.4 TEST the HEPA InTet Temperature alarm as follows:

OPICE $2 y=1 E J W$

OP/CE YUIEJW
8.3.4.1 Instrument Technician DISCONNECT
thermocouple wires from HEPA Inlet thermocouple probe.
8.3.4.2 Instrument Technician APPLY $155^{\circ} \mathrm{F}$ Type $\mathrm{K}$ temperature signal to thermocouple wires. 
HNF-1932 REV 0

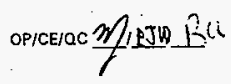

8.3.4.3 RECORD value displayed for TEMP in COMMON FAULT ALARMS group AND

VERIFY that the value is acceptable.

\begin{tabular}{|c|c|c|c|c|c|}
\hline TEMP & ${ }^{\circ} \mathrm{F}$ & 24 & HEPA Inlet Temp & $150-160$ & $|5|$ \\
\hline
\end{tabular}

OP/CEDLIEJW/RG

OPICE $Z \mathbb{R}$ EJW

OP/CERPL EJW

OP/CEMEC, EJW

OPICENIE, EJW

OP/CAN, EVYRa

OPICEME

OPICEMPIETW
8.3 .4 .4

VERIFY that the external alarm strobe and the TEMP icon within the COMMON FAULT ALARMS group are flashing.

8.3.4.5 Instrument Technician RECONNECT thermocouple wires to thermocouple probe.

8.3.4.6 ACKNOWLEDGE alarm on data logger per step 8.3.3:

8.3.5 TEST the Record Sample Flow Variance, Beta Sample Flow Variance, and Beta CAM Failure alarms as follows:

\subsubsection{PRESS VTP-PB-2201C VAC PUMP START SW AND VERIFY button returns to OUT position.}

NOTE: The Record Sample Flow Variance, Beta Sample Flow Variance, and Beta CAM Failure al arms have a 5 minute delay.

8.3.5.2 WAIT 5 minutes before proceeding.

8.3.5.3. VERIFY that the external alarm strobe and the REC VAR, BETAVAR, and CAMFAIL icons with in the COMMON FAULT ALARMS group are flashing.

\subsubsection{PRESS VTP-PB-2201C VAC PUMP START SW AND}

VERIFY button locks into IN position.

8.3.5.5 ACKNOHLEDGE alarm on data logger per step 8.3.3.

8.3.6 TEST the Beta CAM Radiation alarm as follows:

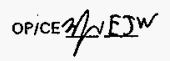

8.3.6.1 Instrument Technician REMOVE wire from terminal 2 on back of Beta CAM.

8.3.6.2 VERIFY that the external alarm strobe and the CAM RAD icon within the COMMON FAULT ALARMS group are flashing. 
OPICE $M$

OP/CARECEJW

\subsection{UNATTENDED OPERATION INTERLOCK}

NOTE: The unattended operation interlock allows the exhauster to run when unattended by interlocking the common fault alarm light to the stack fan.
OPICE W/ETWW OPICEMVIES

OPICEMPUETU OPJCEMR/EIW OPICE HU EJW ETW EXC $2 / 4198$ $m) 1410$

\section{4 .1}

8.4 .2

ENSURE exhauster is in ATTENDED OPERATION mode, and that the exhaust fan has run for at least 5 minutes before proceeding.

\subsubsection{Instrument Technician RECONNECT wire to terminal 2 on back of Beta CAM.}

8.3.6.4 ACKNOWLEDGE alarm on data logger per ștep 8.3.3.
NOTE: The data logger on/off switch is located behind the swing out front video display.

8.4.3 TURN OFF the data logger.

8.4.4 VERIFY that the external alarm strobe is flashing and that the exhauster fan has stopped.

8.4.5 TURN ON the data logger.

8.4.6 PLACE VTP-SS-2208C AUTO SHUTDOWN BYP SW to ATTEND.

8.4.7 RESTART exhauster per steps 8.1.3. 5.2.8 and 5.24 of $70-060-347$.

\subsection{EXHAUSTER AUTOMATIC SHUTDOWNS}

OPIEE LIESW 8.5 .1

ENSURE exhauster is in ATTENDED OPERATION mode, and that the exhaust fan has run for at least 5 minutes before proceeding.

NOTE: The exhauster will automatically shut down if the tank pressure falls below -3 " wg.

OPICE ZIEJW

8.5 .2

Instrument Technician APPLY a gradual7y increasing. vacuum to the low port of VTP-PS-2202C TANK PRESSURE. SW UNTIL exhaust fan stops. 
OP/CE/OC 20,EJW/RQ 8.5 .3

$E \times(\# 4$
JW 214148

$2 / 4 / 45$
OP/CE HS ENW

\section{$8 x^{2}+3$}

OPJCE H, ENW

OPICE YfI EWW

OPICE MEETW

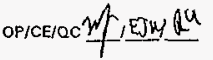

8.5 .4

8.5 .5

8.5 .6
RECORD the pressure at which the exhaust fan shuts down AND

VERIFY the value is acceptable.

\begin{tabular}{|c|c|c|c|}
\hline DESCRIPTION & Mums & ACGERTABine & Aun \\
\hline Tank $P$ & in. wg & $-3.20-(-2.80)$ & $y=3.0$ \\
\hline
\end{tabular}

2.4 .92

Instrument Technician RETURN VTP-PS-2202C TANK

PRESSURE SW to it's original configuration.

NOTE: The exhauster will automatically shut down if the HEPA differential pressure exceeds $5.5^{\prime \prime} \mathrm{wg}$.

8.5.7 Instrument Technician APPLY a graduaTy increasing pressure to the high port of VTP-PDS-2203C HEPA FLT D/P SW UNTIL exhaust fan stops.

8.5.8 RECORD the pressure at which the exhaust fan shuts down AND

VERIFY the vaTue is acceptable.

\begin{tabular}{|c|c|c|c|}
\hline 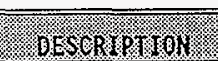 & 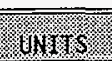 & Acctivinab) & Vinge \\
\hline HEPA Filter DP & in. wg & $5.30-5.70$ & 5.56 \\
\hline
\end{tabular}

OP/CE M, ENW

8.5 .9

Instrument Technician RETURN VTP-PDS-2203C FILTER TRAIN DP SW to it's original configuration.

$\operatorname{Exc} \$ 3$

JU 214198 OP/CEMRLEJW

8.5 .10

RESTART exhauster per step $8.1 .3,5.2 .8$ and $5,2,9$ of $70-060-347$

8.5.11 WAIT 5 minutes before proceeding.

NOTE: The exhauster will automatically shut down if the stack flow falls below 150 SCFM.

OPICE MPVIEJW

8.5 .12

CLOSE VTP-V-2228C FLT BANK INLET ISO VLV gradual7y UNTIL exhaust fan stops.

OP/CE/QQUPN, DWW R 48.5.13
RECORD the flow displayed on VTP-FIC-2205C STACK FLOW CONTROLLER when the exhaust fan shuts down AND

VERIFY the value is acceptable.

\begin{tabular}{|c|c|c|c|}
\hline GESCRYT TroN & Jis & 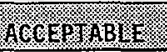 & (matus \\
\hline Stack Flow & SCFM. & $145-155$ & 149.8 \\
\hline
\end{tabular}


1) 214198

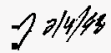

OPICAND/EJN

OPICEYIEJW

OPICEDIESW

OPICE 年,EJW

OPICEIOCON IEJW Ra
8.5.14 OPEN VTP-V-2228C FLT BANK INLET ISO VLV.

8.5.15 RESTART exhauster per steps $8.1 .3 .5,2,8$ and $5.2,9$ of $70-060-397$;

8.5.16 PLACE VTP-HS-2201C HEATER PWR SW to OFF.

8.5.17 WAIT 15 minutes before proceeding.

NOTE: The exhauster will automatically shut down if the stack flow exceeds 250 SCFM for 5 minutes.

8.5.18 Instrument Technician PLACE VTP-FIC-2206C STACK FLOW CONTROLLER into MANUAL mode by pressing the $A / M$ key.

8.5.19 Instrument Technician INCREASE the exhaust stack flow to $250-260$ SCFM using the 1 and $\mathbf{r}$ keys on VTP-FIC2206C STACK FLOW CONTROLLER.

NOTE: The high flow shutdown interlock has a 5 minute delay.

8.5.20 WAIT 5 minutes before proceeding.

RECORD the flow displayed on VTP-FIC-2206C STACK FLOW CONTROLLER when the exhaust fan shuts down AND

VERIFY the value is acceptable.

\begin{tabular}{|c|c|c|c|}
\hline Stack Flow & SCFM & $>250$ & 252,8 \\
\hline
\end{tabular}

OPICE भIEJW

8.5 .22

Instrument Technician PLACE VTP-FIC-2206C STACK FLOW CONTROLLER into AUTOMATIC mode by pressing the $A / M$ key.

\subsection{EXHAUSTER SHUTDOWN AND TAKEDOWN}

EJW 214148

If $2 / x / 48$

Tin 214198

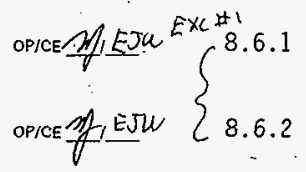

PLACE exhauster into STANDBY MODE per procedure T0-060-347, Section 5.5,3

PLACE exhauster into SHUTDOWN MODE per procedure TO-060-347, Section $5.5 .5,4$

NOTE: Completion of operability testing does not require performance of the following step. The exhauster may be left in place for training or other program requirements. The following step is provided as information to facilitate removal of the exhauster from the test site.

8.6.3 REMOVE RMCS exhauster $C$ per applicable portions of section 5.12 of procedure T0-020-451. 


\section{$\ldots \quad$ HNF-1932 REV 0}

\subsection{INSTRUMENTATION CALIBRATION DATA}

A11 portable instrumentation used by maintenance personnel within this procedure shait be recorded in the table below.

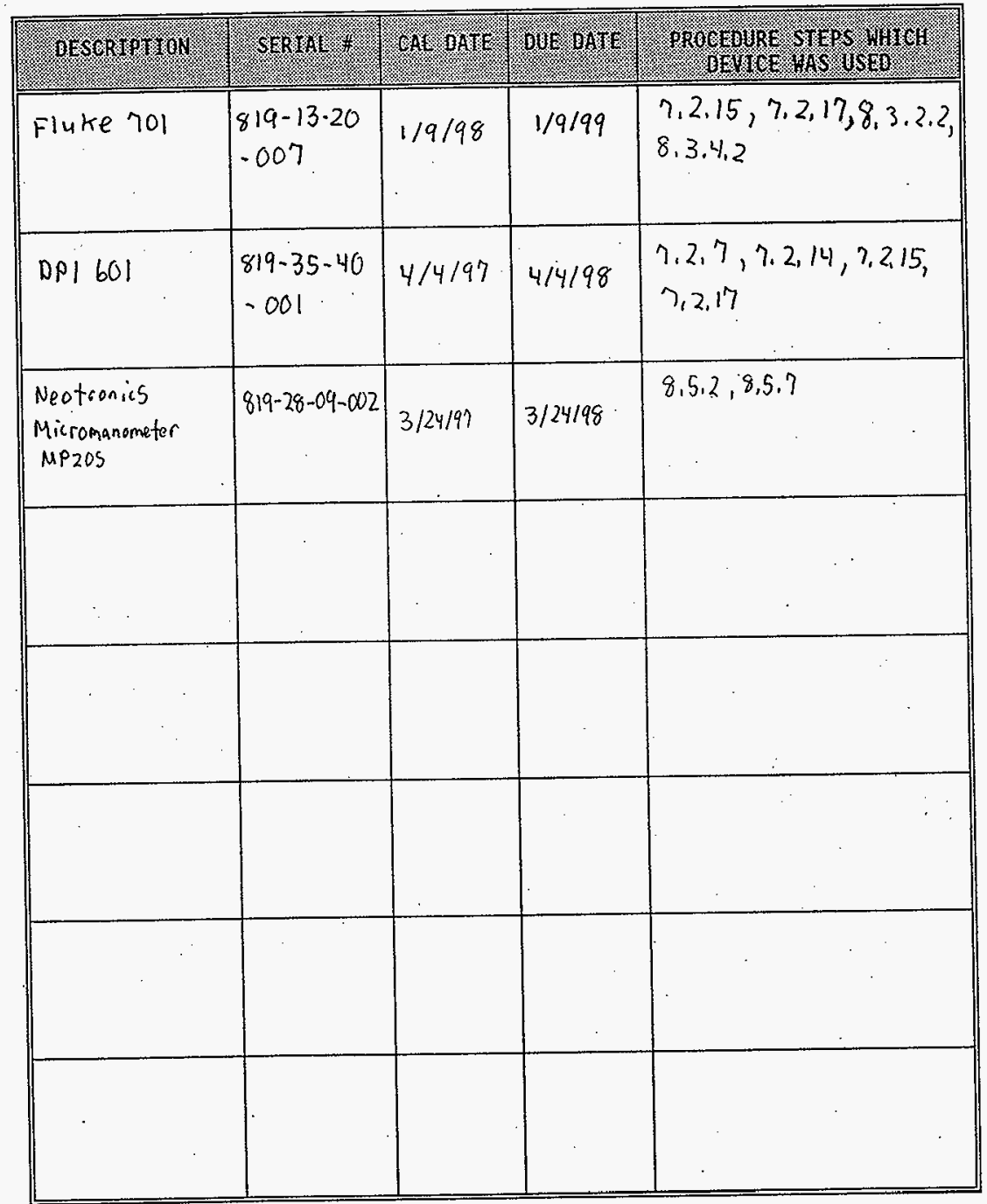


HNF-1932 REV 0

10.0

SIGNATURE LOG

All persons initialing or signing within this procedure (including all data sheets and the test completion sign-off sheet) shall record their signature, initials, and printed name in the table below.

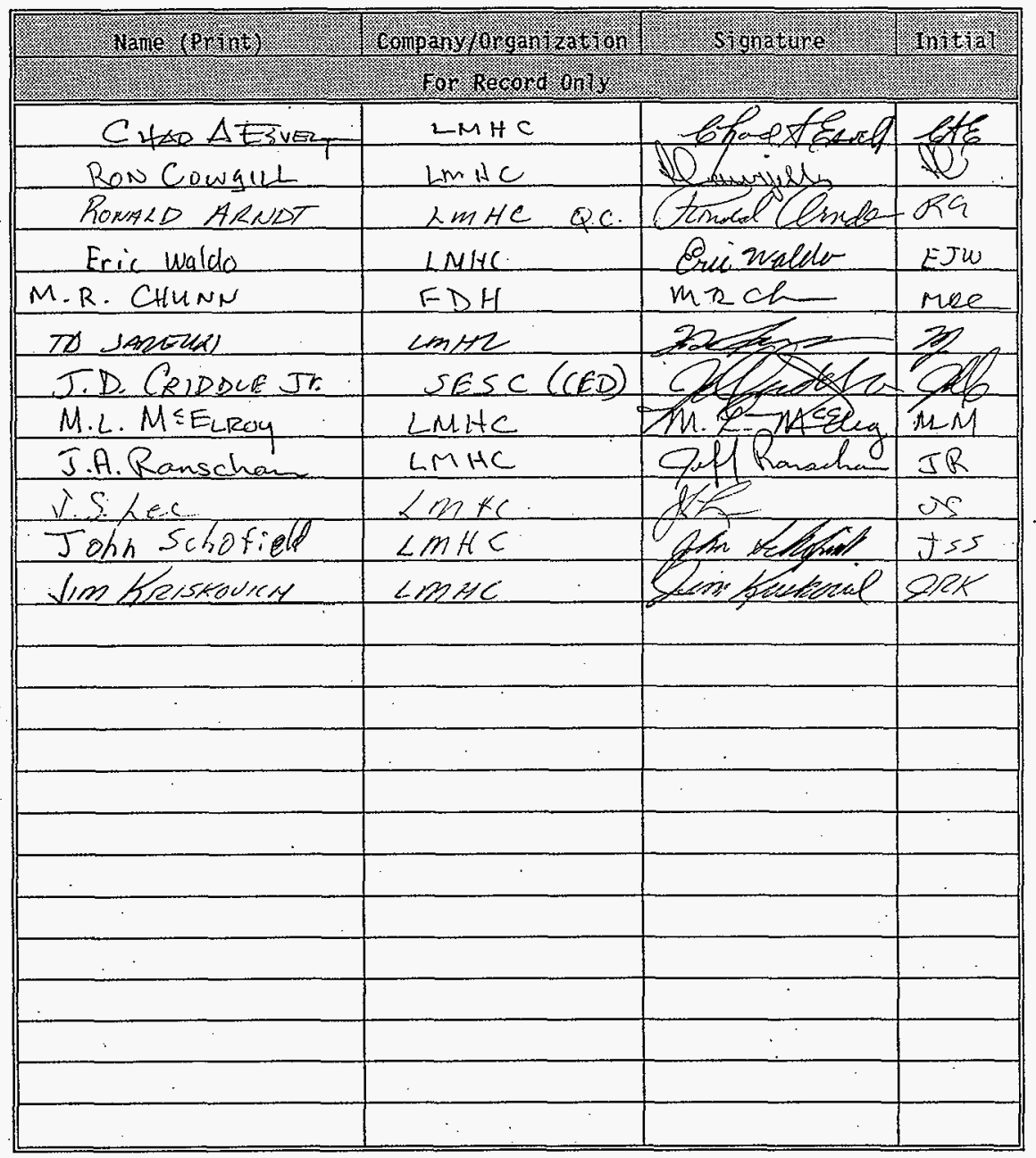

$A=28$ 


\subsection{TEST COMPLETION SIGN-OFF}

All system acceptance and operability tests have been completed as delineated in this ATP/OTP. All exceptions have been documented and resolved as indicated on the Exception / Resolution Data Sheet(s). RMCS exhauster $C$ and associated equipment can be operated in a safe manner and are accepted as meeting all test criteria required for initial RMCS operations in flammable gas tanks.

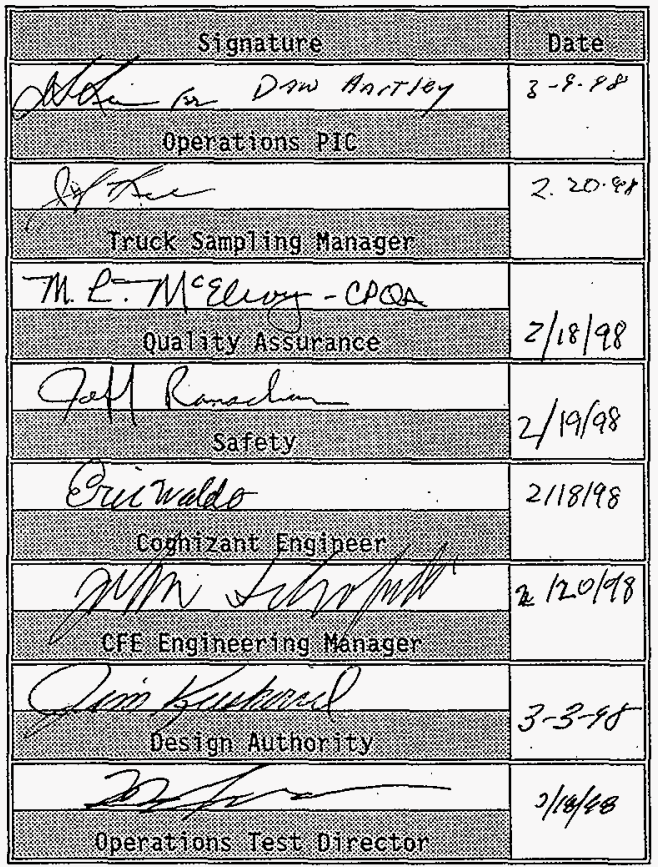




\section{EXCEPTION / RESOLUTION DATA SHEET}

Note: THIS SHEEt IS AN EXAMPLE AND MAY BE REPLACED WITH A SIMILAR SHEET CONTAINING THE REQUiRED IMFORMATION.

\begin{tabular}{|c|c|c|c|c|}
\hline Exception & Step & (1. DESCRIPTION GP PROBHEM & 1.4. RESOLUTON TO PROBLEM & APPROYAL \\
\hline 1 & $\begin{array}{l}8.1 \cdot 3 \\
8.1 .4 \\
8.6 .1 \\
8.6 .2 \\
\end{array}$ & $\begin{array}{l}\text { Steps refer to section numbers } \\
\text { within POP T0-060-347 which } \\
\text { were changed since the OTP was } \\
\text { written. }\end{array}$ & $\begin{array}{l}\text { Correct section numbers were } \\
\text { redi ined into the test procedure. }\end{array}$ & PEu \\
\hline 2 & 8.2 .2 & $\begin{array}{l}\text { Performance of the test } \\
\text { procedure was halted at this } \\
\text { point due to a failed control } \\
\text { Module within the air sampling } \\
\text { control system. }\end{array}$ & $\begin{array}{l}\text { The faulty control module was } \\
\text { replaced and testing was resumed. }\end{array}$ & ${ }_{B G}$ \\
\hline 3 & $\begin{array}{l}8 \cdot 4 \cdot 7 \\
8 \cdot 5 \cdot 5 \\
8.5 \cdot 10 \\
8.5 \cdot 15 \\
\end{array}$ & $\begin{array}{l}\text { Steps instruct operator to } \\
\text { restart exhauster per step } \\
8.1 .3 \text {. The structure of } \\
\text { section } 8.1 \text { was changed prior } \\
\text { to release of the 0TP, causing } \\
\text { these steps to be incorrect. }\end{array}$ & $\begin{array}{l}\text { Correct steps referenced from POP } \\
\text { T0-060-347 were redlined into the } \\
\text { test procedure. }\end{array}$ & METW \\
\hline 4 & 8.5 .3 & $\begin{array}{l}\text { 1: The exhaust fan did not } \\
\text { shut down within the } \\
\text { acceptance range for tank } \\
\text { pressure. } \\
\text { 2. A data value from the HEPA } \\
\text { DP test was inadvertently } \\
\text { entered into the tank pressure } \\
\text { data entry box. }\end{array}$ & $\begin{array}{l}\text { 1. The pressure switch was found to } \\
\text { be out of calibration. Cal ibration } \\
\text { of the switch was performed and the } \\
\text { test successfully completed. } \\
\text { 2. The misplaced value was scratched } \\
\text { out and initialed by QC. }\end{array}$ & $\begin{array}{l}\text { EJW } \\
\text { Ra }\end{array}$ \\
\hline . & & & . & \\
\hline & & & & \\
\hline & & & & \\
\hline & & & & \\
\hline & & & & \\
\hline & & & & \\
\hline & & & & \\
\hline & & & & \\
\hline & & & & \\
\hline & & & & \\
\hline & & & & \\
\hline
\end{tabular}

